Çukurova Üniversitesi Eğitim Fakültesi Dergisi

Cilt: 44 Sayı: 1 Sayfa: 85-104

www.cufej.com

\title{
EFL Teacher's Reflections towards the Use of Computerized Corpora As a Teaching Tool in Their Classrooms
}

\author{
Ali Şükrü ÖZBAY ${ }^{\mathrm{q}^{*}}$, M. Naci KAYAOĞLU ${ }^{\mathrm{a}}$ \\ ${ }^{a}$ Karadeniz Teknik Üniversitesi, Eğitim Fakültesi, Trabzon/Türkiye
}

\section{Article Info}

DOI: 10.14812/cufej.2015.005

Article history:

Received 29 December 2014

Revised 20 January 2015

Accepted 10 March 2015

\section{Keywords:}

Corpora,

Perception,

Teacher training,

\begin{abstract}
The relation between corpus based applications and language teaching in EFL context is far more obvious today, due to the potential of computerized corpus to offer new insights for the language teaching opportunities, which calls for efficient and technology literate language teachers. Although corpus and corpus tools attract a great deal of attention in research community, the use of corpora in EFL classrooms remains limited for various reasons. Part of the reason behind this picture may be due to unpopularity of corpus and corpus tools among the language teachers. Thus, the aim of this case study is to discuss ways of familiarizing language teachers with the potential benefits of the corpus tools and of increasing their perceptions towards it, since this will be an essential step towards the integration of these tools into the classroom environment. To this end, a case study with six (6) language teachers in an EFL context was carried out. Purposive sampling was used in the selection of the samples. Data on the perceptions expressed by the language teachers were collected through open ended interviews. The results suggest that almost all six teachers favored the language exploration process through a range of concordance searches on structural and lexical aspects of language but added that the potential of corpus to offer wide range of grammatical structures and lexical patterns at one time may be difficult to grasp for themselves as well as for their students in the classroom.
\end{abstract}

\section{İngilizceyi Yabancı Dil Olarak Öğreten Ögretmenlerin Dil Sınıflarında Bir Ders Aracı Olarak Bilgisayarlı Derlem Kullanımına Yönelik Düşünceleri}

\section{Makale Bilgisi}

DOI: $10.14812 /$ cufej.2015.005

Makale Geçmişi:

Geliş 29 Aralık 2014

Düzeltme 20 Ocak 2015

Kabul $\quad 10$ Mart 2015

Anahtar Kelimeler:

Derlem,

Algı,

Öğretmen yetiştirilmesi.

\section{Öz}

Etkin ve teknoloji okuryazarlığı iyi olan yabancı dil öğretmenlerinin varlığını gerekli kılan bilgisayarlı derlem uygulamaları sayesinde, yabancı dil öğretiminin önünde yeni ufuklar açılmış ve derlem tabanlı uygulamalar ile dil öğretimi arasındaki ilişkiyi günümüzde çok daha belirgin şekilde ortaya çıkarmıştır. Derlem ve derlem araçları araştırmacılar arasında bilinmesine ve ilgi çekmesine rağmen çeşitli sebeplerden dolayı dil öğretiminde hak ettiği ilgiyi henüz görememiştir. Bu durumun sebeplerinden bir tanesi derlem ve derlem araçlarının yabancı dil öğretmenleri arasında popular olmaması olabilir. Çalışmanın amaçlarından birincisi, derlem ve araçlarının potansiyel faydalarını yabancı dil öğretmenlerinin daha fazla tanımasını sağlamak ve onların farkındalık seviyelerini artırmaktır. Bu durum derlem ve araçlarının dil sınıflarına entegrasyonu için gerekli bir aşamadır. Bu örnek olay incelemesi altı İngilizce öğretmeni ile gerçekleştirilmiştir. Deneklerin seçiminde amaçlı örnekleme modeli kullanılmış ve dil öğretmenlerinin konu hakkındaki algıları açık uçlu mülakat ile belirlenmiştir. Tüm denekler İngilizcenin yapısal ve terimsel yönleri üzerine derlem dizinlerinde yaptıkları yeni keşiflerden çok memnun kalmışlardır. Derlemin kullanıcılarına potansiyel olarak sağladığı dilbilgisi ve kelime yapıları hakkındaki alanın anlaşılmasının kendileri ve öğrencileri açısından zaman alabileceği ifade edilmiştir. 


\section{Introduction}

It is a long consensus by now that with the integration of technological tools, especially the computer, language studies around the globe have taken a new turn. These dramatic changes were felt mostly in the way that the languages are studied and thus the scope of the boundaries for the language studies have been extended far beyond. In fact, the emergence of computerized corpus and its widely available applications to the language studies are among the concrete examples of what can be done in linguistic research with a computer. Computerized corpus studies have become popular thanks to the advances in computer technology, through which it has become largely possible to store, explore and analyze large language data through concordance component of corpus. The use of computerized corpus for language pedagogical purposes started with the COBUILD learner dictionary project in 1987 by Sinclair (1987). This is followed by the compilation and analysis of learner corpora such as ICLE by Granger (1998) and her corpus research team. This and many other corpus based studies showed that the relation between the corpus linguistics and foreign language teaching should be established firmly and that corpus, corpus tools and corpus methodologies offer a lot for use in language teaching.

Corpus linguistics presents us with profound changes in the way that we study, teach and learn languages all over the world due to its huge potential to present entirely authentic and genuine samples of language use. A well-known definition of "corpus" as a compilation of language chunks that are stored and accessed on a computer entails further consideration of the "performance" data as a way of accessing a huge amount of naturally occurring data that makes it possible to carry out linguistics investigations based on real data. It is also the case that corpus and corpus tools empower language teachers with a very rich and effective means to be able to use and teach the language closer to the norms of a native speaker. However, to be able to use the corpus efficiently, there is a need for language teachers to learn how to evaluate the findings. A large sum of documentary that teachers are likely to find from corpus search may not be an easy task to work with.

These corpus-based applications soon prepared the ground for the question of how to use corpus data and corpus-linguistic methods for the language teaching and learning purposes (Burnard \& McEnery, 2000; Aston, 2001). Efforts to incorporate corpus into the actual language teaching seem missing and the awareness towards corpus and corpus tools is very low and, in some cases, there is a resistance toward corpora from students and teachers. It is an irony to note that many teachers of English are using the corpus-based language materials such as dictionaries and grammar books in their classrooms without actually being aware of this. According to a survey carried out by Mukherjee, $80 \%$ of the 248 secondary school teachers in Germany accepted that they had never even heard of corpora (Mukherjee, 2004), reinforcing the idea that there is a long way to go before corpora can be understood and used by language teachers in general (Mukherjee, 2004; Boulton, 2009; Frankenberg-Garcia, 2010; Gilquin \& Granger, 2010). In spite of the several indirect applications of corpus based materials, the direct use of computerized corpus for the language teaching and learning for the time being is limited to a few classrooms as stated above. According to Tribble (2000, p. 31), this situation is due to the fact that "not many teachers seem to be using corpora directly in their classrooms". This contention is further supported by Seidlhofer (2002, p.216), who stated that "the awareness level of teachers and students is very little towards the influence corpus linguistics has on the preparation of the language teaching materials and reference tools". Referring to the situation in EFL settings, Mukherjee $(2004$, p.239) noted that "the influence of computerized corpus-linguistic research on the actual practice of language teaching is still relatively limited". The lack of pedagogic interest towards corpora and corpus tools in language classrooms is widespread and according to Braun (2005) "corpora is still far from being part of overall teaching practice in the language classroom" (p. 48).

The lack of application of computerized corpus tools in the language classrooms brings about the problem of how we can successfully integrate computerized applications into language teaching. In order to break this resistance, initially teachers need to be informed about the availability of useful resources and to start working with corpus, computers and concordances themselves since the number of those who do so is relatively few, if not at all (Mukherjee, 2004). Secondly, it is also necessary to 
prepare the ground for creating more corpus based language materials which reflect actual language use unlike those that still differ considerably from actual language use (Römer, 2005).

Thirdly, classroom activities based on data-driven learning as suggested by Johns and King, (1991), Tribble and Jones, (1997), Aston (2001), Sinclair (2004), Bennet (2010), and Reppen (2010) can be promoted in the classroom so that language teachers will seize the opportunity to tap the benefits of corpora themselves and for their students. Finally, it is important to note that the use of corpus in the language classrooms may help raise the language awareness of the teachers in ways not anticipated before. It can also help teachers to reflect on their knowledge of the language and to discover the rationale for their decisions related to language (Allan, 1999; Hunston, 1995).

The use of corpora in language classrooms largely depends on the teachers' familiarity and experience with the corpus tools such as concordances. It is the language teachers who can incorporate corpora and corpus tools into their teaching since they play significant roles in the process of introducing corpus work into the classroom. It is also the case that this experience with corpus tools must be broad and sufficient enough to enable teachers to integrate it to their teaching. For this to happen, though, there is a need for teachers to "become literate in corpus" (Mukherjee, 2002, p. 179). Increasing teachers' awareness and developing their corpus skills are important factors for their teaching and that will further contribute to their developing language skills (Hunston, 1995; Tsui, 2004; Farr, 2008). The first thing to do is that they should become learners and experience corpus skills for themselves since they need to guide the learners for corpus based activities in the classroom. Secondly, teachers "play important role in the process of re-contextualizing corpora and any useful findings from corpus-based description" (O'Keefe \& Farr, 2003, p. 391), and "mediation by the teacher is a necessary prerequisite for successful application of computer corpora in language teaching and should therefore be given sufficient attention in teacher education courses" (Kaltenbock \& Mehlmauer-Larcher, 2005, p. 81).

However, all these may not be easy for teachers to accomplish unless we know the extent of skills in the use of corpus. To apply more widespread corpus based language activities in the classroom may be challenging. It is, therefore, necessary to better understand and solve the problems language teachers are likely to encounter while using corpora in the classroom. For instance, some teachers may not be good enough to teach learners how to use the results of the corpus analysis since "the control is given to student-initiated corpus findings and the teachers' authority may thus be threatened by the students and their concordance findings, especially when there is a gap between these findings and the teachers' explanations" (Johns, 1991, p. 3). What is more, the number of corpus-based classroom materials is still limited and teachers have the responsibility to adjust them suitably to the classroom use, which presents an extra work with teachers.

The researchers of this study hold that teachers should be aware of corpus based approaches and their successful implementations in their classrooms. Their knowledge of how they can integrate corpus tools into their teaching, what corpus based methods to use and when they should use them are directly related to their perceptions of corpus. According to Woods (1996), perceptions of teachers about their teaching play an important role in their decisions, judgments, and behavior in the class. Moreover, Seidlhofer $(2002$, p. 216) stressed that "the awareness level of the language teachers towards the huge potential of corpus to describe language and to prepare the language teaching materials is an significant factor that has to be considered seriously". Consequently there is a need to investigate and increase these perceptions for the purpose of reaching a consensus as to which aspects of corpus tools should be considered as important and to what extent these considerations should be integrated into the actual classroom atmosphere. Under the light of what has been discussed so far, we believe that EFL teachers' perceptions towards the integration of corpus tools inti actual classroom teaching must be investigated. A thorough analysis of these perceptions is important for two more reasons. The first one is that investigating teacher perceptions towards the integration of corpus as a language teaching methodology gives us a chance to understand how corpus tools can be exploited by teachers as well as the students. The second is that through analyzing teacher perceptions, it may be possible to see what successful or 
experienced teachers are doing with corpus tools in their classrooms that make their courses effective and what other teachers, usually inexperienced or unsuccessful ones, are missing in the implementation of their courses

\section{Method}

The idea behind this study which is qualitative in nature is to find out tertiary level EFL teachers' perceptions of the possible roles and integration of corpus and corpus tools into English Language Teaching (ELT). These perceptions may reveal the true nature of the EFL teachers' stance towards corpora. It is also hoped that the findings will help us see whether the use or the integration of corpus tools to an EFL context is possible. As a result of this study, it will also be possible to see whether EFL teachers consider corpus as an important methodology to be used in EFL contexts or merely an alternative to paperback dictionaries by presenting a broader scope of contextual information for the words.

Another rationale behind this research is that it gives us a true picture of many high and low frequency linguistic items. The researchers of this article claim that these linguistics items need to be considered carefully before any EFL curricula is prepared. Failure to do so, however, may create an EFL curriculum which gives little pedagogical attention to linguistics items with a high frequency of occurrence in corpora (Biber et al. 1994). We believe that when language teachers are informed about the possible benefits of computerized corpus and corpus tools to be used in the classroom, then they can be expected to seize the opportunity to explore corpora at least in terms of high and low frequency linguistic items as learners and teachers. Thus, they may help learners learn the target language more efficiently, particularly in intermediate and upper intermediate levels. Put it in another way, EFL teachers can discover the potential of corpora as part of their own teaching and learning. When they find their learning and discovery process with corpora to be beneficial, then it may be possible that they may decide to use corpora while teaching in the classroom. This will, in turn, popularize corpus and corpus tools in the classroom and among the learners respectively. This was the main rationale for conducting the case study, which we will present in the following section.

This study sought to answer the following questions:

1. How is the role of corpus-based classroom teaching in the EFL curriculum as perceived by English teachers teaching in EFL settings?

2. Have EFL teachers received any training so far in teaching with corpus?

3. What are EFL teachers' priorities in using corpus?

4. What features of corpus tools do EFL teachers consider as important in teaching their students?

\section{Research Design}

The present case study was carried out to seek ways to integrate computerized corpus linguistics tools into language teaching and learning process. Six EFL teachers were the participants of this case study and they were given a total of eight-week training, three hours each week in the form of a workshop. The purpose was, first of all, to create an adult learning experience for the subject teachers in line with the Kolb's (1984) "experiential learning cycle" that is based on the premise that adults learn through concrete experience, observation and reflection and then, they were asked to change into teacher roles and seek ways to use their corpus experiences with their teaching. During the workshop period the subject teachers created corpus-based teaching activities that can be used as complementary while teaching. They were also expected to arrive at conclusions based on "a reflection of their own language learning experiences and on an ongoing reflection of their classroom teaching" (MullerHartmann \& Schocker-von Ditfurth, 2004, p. 9). 


\section{Participants and Setting}

This study was conducted in the year 2013 with six (6) EFL teachers, teaching for the prep-classes in the School of Basic English, at Karadeniz Technical University. In the selection of samples purposive sampling was used and thus, the participants were selected by the researchers upon the availability and willingness criteria. All the subjects were teaching grammar, reading, writing and listening in English preparatory classes for an average of 30 hours a week. These teachers used the same course materials, but were free to bring their own materials to their lessons. There were 67 classes in the school, and the students came from many different departments. The participants of this study were very eager to take part in the study because they taught that the training of corpus and corpus tools would assist them to gain insight into their teaching and help implement successful classroom teaching. The subjects' previous and current exposure to English outside the classroom did not vary significantly. Most of the subjects clearly stated that they only used English in the classroom. Out of six subjects only four had participated in seminars or certificate programs in ELT and almost $60 \%$ of the subjects did not receive any formal education in English language teaching (ELT), since the university administration does not require a formal ELT background from their teachers. One common attribute was that all six lecturers continued the previous language teaching traditions in terms of the curriculum and the content.

The reasons for selecting these teachers were two-fold. First of all, within the scope of this study, we thought these teachers would fit the required conditions such as computer literacy and young age. The second reason was related to one of the limitations of the study, that is, our geographical location. There is only one university with a preparatory school foundation in Trabzon and the other universities are far from the location. Table 1 below summarizes relevant subject characteristics.

Table 1.

Demographic Information of Teacher Participants (Subjects).

\begin{tabular}{llrr}
\hline & & No & $\%$ \\
\hline Sex & Female & 6 & 100 \\
Age & $23-29$ & 5 & 80 \\
& $30-36$ & 1 & 0 \\
& $37-44$ & 0 & 0 \\
Years of profession & 45 -above & 0 & 0 \\
& & & 20 \\
& Less than a year & 1 & 60 \\
Undergraduate degrees & $1-4$ years & 4 & 20 \\
& $5-8$ years & 1 & 0 \\
Degrees or Qualifications in ELT & 0 & 20 \\
& $9-14$ years & 1 & 80 \\
& Teaching English as a For. Lang. & 5 & - \\
& English Language and Lit. & - & - \\
& MA (Master of Arts) & 2 & - \\
& Certificate & - & - \\
& Summer School & 2 & \\
& Seminars & &
\end{tabular}




\section{Data Collection Tools}

\section{Training EFL teachers to teach with Corpus and Corpus Tools}

The training workshops were done at the School of Foreign Languages of Karadeniz Technical University in Turkey, in spring term of the academic year of 2013. They lasted for 8 weeks with twohour weekly sessions. These workshops were done in the computer lab, which was equipped with individual computer stations connected to the internet. Corpus resources available to the subject teachers included Karadeniz Technical University Corpus of Learner English (KTUCLE), AntConc 3.0.1 (Anthony, 2004), British National Corpus (BNC), Corpus of Contemporary American English (COCA) and British Academic Written English (BAWE) available online. Six EFL teachers (all females), aged between 24 and 30, participated in the course. None of the participants had previous knowledge of corpus linguistics. According to the Aston (2000), there are basically three fields for which corpus data can be used in ELT and this systematization was the main reason behind the structure of the workshop sessions, these being;

1. Introduction: Teaching corpora. Equipping them with the basic skills for corpus-based language analysis.

2. Exploitation: Helping them teach with concordancing software.

3. Transformation: Helping them discover ways of using corpora in their teaching.

(Aston, 2000. p.7)

The above systematization was used in the study. During the introductory sessions such corpus activities as comparing words and collocations, creating POS lists and KWIC searches were done and these were mainly teacher based activities as described by Flowerdew (2001), Granger and Tribble (1998). Finally, some surprising corpus based findings were shared with the subject teachers.

The first three workshop sessions have shown that the subject teachers were sharply interested in corpus findings and they wanted to learn more about corpus. For example, all subject teachers were surprised when they noticed that the use of "Simple Present Tense" is quite unlike to its definitions in three reference grammar books. The reference grammar books mark the "Simple Present Tense" as mostly used to refer to "habitual actions" in the first rank. However, a quick search on the COCA corpus has revealed that in all the registers included, the "habitual action" rule was proved correct in no more than a few sample sentences. On the contrary, the Simple Present Tense was observed to be used to refer to "already existing situations", especially with the verb "be" in all forms. This and other surprising findings proved that there may be many other examples of corpus-based findings that question the validity of the ways English language teachers go about correctness in language. The intuitive knowledge that is used by many language teachers for their language related decisions faces huge challenges by the corpus findings. During the exploitation session, practical problems that all teachers encounter while teaching were picked up and further elaborated with the corpus examples. This is expected to give subject teachers hands-on practical experience with corpus as a helpful and problem-solving tool. These problems include the differences between written and spoken languages, lexicology, comparison of learner corpus findings with the native, showing the extent of overuse and underuse of lexical elements. The subject teachers gradually but firmly began to establish very close relations between corpus findings and their significance for the language learning and teaching. During the transformation stage the participants teachers were asked to transform their corpus skills into their actual teaching. 
Table 2.

The Workshops Sessions And The Topics Covered On A Weekly Basis.

\begin{tabular}{lll}
\hline Duration & Systematization & Procedures \\
\hline Week 1 & Introduction & $\begin{array}{l}\text { Definition of Corpus, Corpus types, Word lists Concordances, } \\
\text { Frequency data, Registers, Genres, BNC, COCA, KTUCLE, } \\
\text { BAWE, AntConc 3.0.1, The notion of representativeness }\end{array}$ \\
Week 2 & Exploitation & $\begin{array}{l}\text { Selected findings from corpus based research, examples from } \\
\text { frequent lexico-grammatical patterns of a given word }\end{array}$ \\
Week 3 & Exploitation & $\begin{array}{l}\text { Lexical analysis of some common words through corpus in } \\
\text { terms of underuse and overuse. }\end{array}$ \\
Week 4 & Exploitation & $\begin{array}{l}\text { Structural (Grammatical) analysis of tenses and common } \\
\text { adverbials through corpus ( for example: "if clauses") }\end{array}$ \\
Week 5 & Exploitation & $\begin{array}{l}\text { Simple Present, habitual actions, existing situations, plans, } \\
\text { fixed events, future use }\end{array}$ \\
Week 6 & Exploitation & Usage based analysis of Modals: Must, should, can ... \\
Week 7 & Exploitation & Collocations, lexical bundles, recurrent word comb. in the \\
learner corpora ( KTUCLE versus BAWE)
\end{tabular}

\section{Data Collection Instrument: Semi-structured Interview}

Best and Kahn (1998) describe interviews as a data collection process during which the subjects give the needed information orally and face-to-face, which may provide the researchers with insights and a true understanding of the topic he is investigating (Best \& Kahn, 1998; Oppenheim, 1992; Blaxter et al. 1996). In this study, a semi-structured interview was used since it was considered as flexible (Cohen \& Manion, 1995). It also allows researchers "a depth to be achieved by providing the opportunity on the part of the interviewer to probe and expand the interviewee' responses" (Hitchcock \& Huges, 1994, cited in Kayaoğlu, 1997, p. 49). For this purpose in the course of this study, a semi-structured interview composed of open-ended questions was conducted with the subjects. Each interview took approximately 30 minutes and all the subjects preferred to be interviewed in their rooms. The answers were rather short, so the process of transcription was not long. In order to ensure the reliability of the interviews same or similar questions were restated during the course of each interview. After the interview was over, a friendly talk with each of the subjects ensured that the responses given during the interviews were almost the same.

\section{Findings}

This study investigated tertiary level EFL teachers' reflections towards the use of computerized corpora as a new teaching tool in their classrooms. In part, this study aimed to find out whether EFL teachers are aware of the corpus based approaches and techniques in their teaching and if so, their perceptions of the role of corpus based classroom teaching in the curriculum. The reason for this 
emphasis was that the investigators thought there might be a close relationship between teachers' perception towards corpus based approaches and their teaching. Their previous experience in corpus, priorities regarding corpus use and the awareness towards the potential features of corpus tools were the further points of investigation. In order to collect data open ended interview was used, and this case study was conducted with $6 \mathrm{EFL}$ teachers currently teaching in the preparatory classes of Karadeniz Technical University.

\section{Question 1: Have EFL teachers received any training so far in teaching with corpus?}

The first research question asked whether the subject teachers had received any training in teaching with corpus before the actual study was conducted. The responses to this question were various in scope and extent. T1, for instance, stated that she was not familiar with the term "corpus" even from her university years, indicating that the term is completely new to her. In fact, this response may not be surprising if we consider the low level of awareness towards the corpus linguistics as a discipline and corpus tools as potential means of teaching and learning language. What is more, the lack of focus and attention in the curriculum of the English departments in Turkey towards the use of corpus is likely to be another important factor behind this picture. The accounts of T6 and T2 also indicated that they had no previous training with corpora and that they had never used it in their classrooms. The responses given by these subjects clearly indicate that the subject teachers had no previous experience of corpus and corpus based language teaching research either as students or as teachers. T6 's account of "first time working experience" with corpus indicates that the language teachers within the scope of this study need to be trained for the use of corpora in the classrooms. T2's response to this question also shows that language teachers may have very limited amount of familiarity with the corpus as a cover term but this familiarity is not strong enough to integrate it into the classroom. The following quotations depict the commonly shared view:

Teacher 1: “..... Not actually, I wasn't familiar with the topic and I don't remember

much from the university years having read or heard of anything related to the word

corpus and its applications whatsoever".

Teacher 6: "This was my first time working with corpora and so no training or

familiarity with corpora before......".

Teacher 2: ".... I had heard about it but I didn't know much about it and no way

ever thought of using it in my classroom".

Similarly, T3's account of corpus training below shows that there was a limited amount of familiarity with the corpus, which seems to have remained only in theory and with no practical results whatsoever. In other words, in spite of the fact that they had some familiarities with the corpus linguistics as a title or chapter of a reference book their actual knowledge of corpus based methodologies and their successful implementation in the language classrooms seems to be very limited, if not at all. The participants' answers also reveal that corpus-based methods have not yet exerted much influence on teaching practice in the English classroom in the school as highlighted below:

Teacher 3: "I was familiar to corpus linguistics to some extent but I had no idea of

how to use it in my classroom until recently".

Teacher 4: "Before I heard the word "corpus linguistics" but I wasn't familiar with the

BNC or COCA links where I could make searches and ...".

Teacher 5: "I had just heard about the corpus before, but I didn't know how to use it and what it was used for...". 
T5 and T6 below, regarding the first research question added that the workshop sessions that were held within the scope of the study gave the subject teachers a chance to discover more about corpus and corpus based classroom applications. This indicates that more exposure to corpus linguistics as one branch of a broad area of Applied Linguistics and corpus tools through various pre-service training activities may foster their interest and help them realize and appreciate the true benefits of it. Based on the T6's account, it may be possible to conclude that using corpus efficiently help language teachers to make well-informed decisions related to the various aspects of language forms as indicates in the following reports:

Teacher 5: "... after the workshop I had the chance to learn about corpus in detail".

Teacher 6: "...in the workshops I realized the potential benefit of corpus as an ideal

tool for us as well as our learners in its capacity to help use chose the correct forms

when we look at many examples and compared the usages".

Under the assumption that the interview results are more or less representative, the answer to the very first question clearly illustrates the low extent to which corpus linguistics has so far had an impact on teaching practice in the language classrooms. It is also the case that the lack of awareness of language teachers towards the potential of corpus tools in language teaching may lead them to make wrong decisions related to the language forms and their functions in the texts, which is obvious from the T6`s account.

Question 2: How is the role of corpus-based classroom teaching in the EFL curriculum as perceived by English teachers teaching in EFL settings?

The second research question dealt with the participants' perceptions about the role of corpus based classroom teaching in the EFL curriculum. The amount and the contents of the responses to the second question show that all participant teachers felt that English language teaching may profit in one way or another from the use of corpora. Moreover, the participants were found to hold the view that use of corpus data would be beneficial not only for themselves but also for their students. T1, T2 and T3's responses to this question indicate the high level of awareness that subject teachers have towards potential benefits of corpus for their students who will use them to correct their structural errors.

Teacher 1: "... I believe that the teacher or the learners may profit from corpus...".

Teacher 2: "... Yes they may benefit from corpus data".

Teacher 3: "... Corpus may be beneficial both for the students and teacher".

Teacher 4: "... Corpus will be beneficial if we spend time on it".

Teacher 5: "... Ss are prone to make mistakes while making sentences especially when the target language and source language aren 't close to each other. They can use corpus and correct the general grammatical mistakes and also it offers the daily expression in the target language".

The participant teachers also stated that the language proficiency level of the learners was yet another important factor behind the efficient exploitation of corpus and corpus tools in and outside the classroom. The widespread point of view shared by almost all subject teachers is the corpus user's language proficiency. It is also evident from the literature that high intermediate and advanced level learners can use corpus tools much more efficiently than the lower proficiency groups. T4, T5 and T6 stated that corpus is basically for advanced or high level learners while T1 draws attention to the fact that corpus search results may be difficult to grasp for beginners. The teachers' accounts of level dependency is also consistent with the Hasselgård and Johansson's (2011) contention of advanced language learners who are prone to make mistakes and may have language knowledge which is limited in scope when compared to native speakers of the target language. 
Teacher 4: "... If the level of the students is advanced, they may profit from the corpus because it may be difficult to use and understand the meaning/purpose of the corpus for beginner or elementary students".

Teacher 1: "... but the level of the learners is quiet important here. For beginners, it may be challenging".

Teacher 5: "... it is designed for higher level learners rather than beginner ones".

Teacher 6: "... I think only the best students can use this tool efficiently but the others don't".

One subject teacher drew attention to the "field dependency" nature of corpus based applications, which is based on the premise that there are some fields or registers that have much greater potentials to offer solutions or findings unlike those which do not.

Teacher 2: "... the amount of the obtained profit can be changeable from one field to another"

Another subject teacher expressed her frustration with the so-called user friendly nature of corpus interface.

Teacher 3: "... sometimes you can forget one step in corpus and you should reset what you have done to find the word.to reset takes your time..."

In fact, the reasons of these perceptions above may partly be related to the corpus literacy and corpus skills of the users or learners rather than the corpus itself. An expert corpus user is thought to equally benefit from findings in each field. The findings above also indicate that subject teachers consider the potential benefits of corpus not only for themselves but also for their students. In fact, this agreement between teacher-centered corpus activities and learner-centered ones shows the increasing tendency to focus on corpus-based activities that are carried out by autonomous learners and the subject teachers think that corpus data are useful for them as well (Bernardini, 2000; Gavioli, 2001).

\section{Question 3: What are EFL teachers' priorities in using corpus?}

The third question was related to the participants priorities in using corpus. The important point here is that some subject teachers, in answering the third question, exclusively focused on the use of corpus as a tool in academic writing and writing courses in general rather than other language skills such as speaking and reading. The potential of corpus to offer a large amount of language samples that are authentic and that are taken from the real life and that can be grouped under different registers make it an ideal tool for academic and expository writing. Furthermore, the responses below reveal that there is a good room for teachers to use corpus tools while teaching the language and at the same time learners may use it while learning the language. One teacher (T3) even suggested that corpus can be used to discover more about "spoken" language under the spoken register.

Teacher 1:"Consulting or using corpus data may offer help to L2 writers in academic writing courses. Or students can use it in many ways thanks to its large context and texts from different subject areas"

T1's priority in using corpus was academic writing. S/he stated that corpus has the potential to provide various benefits to the academic writing students. T2, T4 and T5 also suggested that corpus may help students write better.

Teacher 2: "First of all I think that I can consult corpus data for writing courses..."

Teacher 4: "It would be helpful for L2 learners in writing courses while also they were writing articles and essays in their courses"

Teacher 5: "As for teachers it may be useful in writing course" 
Teacher 3: "Corpus would be helpful if I were writing my thesis, so I would consult it in academic field. At the same time it gives us the chance to catch up with the spoken language. So I would use it to learn about the daily language"

The subject teachers (T2 and T6) also stated that corpus findings can be used in translation as well as in writing. According to T5, the students who use corpus while translating may distinguish between the words in terms of usage and increase collocational awareness by actively selecting the words that go together in translation.

Teacher 2: "First of all I think that I can consult corpus data for writing courses and translation works".

Teacher 5:"To compare the appropriateness of two words or collocations, to find the most appropriate word for another word."

Teacher 6: "I think corpus is very useful for checking the words going together and we can get use of it in the translation."

Participant teachers' tendency to use corpus for translation and appropriate word selections purposes is also important in the sense that corpus has a wide range of other benefits for language teachers as well as students. In line with the T5 comment, finding the most appropriate word for any given context has always been a challenge and corpus tools help overcome this challenge.

\section{Question 4: What features of corpus tools do EFL teachers consider as important in teaching their students?}

Question 4 asked their ideas related to the features of the corpus tools that they consider as important in teaching their students. The subject teachers were expected to learn the types of activities that would be useful in classroom teaching and they were asked to list the activities that they found particularly useful and that they would intend to put into practice in their own classrooms. Several subject teachers expressed their opinions in favor of concordances as follows:

Teacher 1: "I think corpus concordance is a very useful tool for comparing the words going together and we can make use of it in the translation".

Teacher 2: "Concordances provide contextual usages and they are really useful".

Through the corcordances, they were able to compare the words and find the right collocates as well as determining the exact contexts of any given word. They also were able to observe the differences in terms of usage between the two verbs which seem to have similar meaning such as "begin" and "start" and the possible noun forms that immediately precedes or follow them.

Teacher 4: "From concordance data we know which nouns can come first after "start", or what words can come following "begin".

We believe that the aspect of corpus concordances to provide natural, authentic and comparatively reliable picture of any given item is one of the biggest strengths of it and in fact it seems from this relatively small scale study that the subject teachers also favored this aspect of corpus. During the workshops sessions we observed the very positive attitudes of these teachers towards concordance tools.

Teacher 3: "See collocates, which words are used with other words, verbs and so on."

Teacher 6: "The most important profit is that we can limit the context choosing a field, which is not available in dictionaries." 


\section{Sample training workshop}

In one of the training workshops that were done with subject teachers (Week 4) they were given a sample sentence from "If Conditional" and asked to comment on this sentence in terms of correctness or suitability within the scope of their general understanding of the English grammar. The sample question below was taken from another study that was carried out by Murherjee (2004) and the teachers' comments regarding this question were given below:

\section{Table3.}

Sample Question From The Workshop Sessions.

Week 4: Exploitation: Mark as correct or wrong and why?

"I would be grateful if you would send me more specific information"

Teacher 1: "Actually in grammar point this sentence is wrong because we learnt from grammar books that we don't use modal verbs after "If". However, we can use "would" in order to express politeness after "if". We can encounter with this example in corpus"

Teacher 2: "To be honest I would say that this sentence is wrong because of "would" coming after the conditional. However, when I consult corpus data during the workshops, I became aware of the fact that the use of "would" after the conditional can be possible."

It is evident from the teachers` $(T 1, T 2)$ account above that both teachers have some mixed opinions related to the accuracy of the given sentence.

T1 claimed that this sentence is wrong in terms of formal grammar framework, adding that the grammar books do not have such a "if + would" form. In the case of polite requests, however, she said this combination is possible. This teacher finalized her comments by offering a corpus consultation in order to prove the existence of if + would combination for polite requests. With this in mind, however, she offered neither a general framework of usage within which this structure would closely fit in, nor did she make any clear-cut explanation regarding the use of this form other than it could be used in polite requests.

T2 similarly claimed that this sentence is wrong because "would" does not normally come after the conditional. However, after a corpus search, she realized that this structure can be possible.

Teacher 4: "We use these modals in main clauses not in if clause"

Considering the T4`s interpretation of this structure as incorrect, assuming that the modals do not appear in "if clause" part of the sentence, it may be possible to conclude that lack of corpus tools in the language classrooms would result in language use which is limited in terms of variety and scope.

Teacher 3: "That is correct because this sentence means that the speaker will be happy if she takes more information. She is using 'would' after if I order to be more polite, so that is not wrong"

T3 considered the sentence as correct, described the meaning of it and finally added that the sentence can be acceptable as a form polite request.

\section{Question 5: What types of dictionaries are you using?}

During the training workshop we asked the subject teachers to name the types of the monolingual English dictionaries they often use. Most of the dictionaries which are used by the subject teachers below are corpus-based ones, which include sample sentences from the natural and authentic contexts taken from a large corpus database. 
Ali Şükrü ÖZBAY, M. Naci KAYAOĞLU- Çukurova Üniversitesi Eğitim Fakültesi Dergisi, 44(1), 2015, 85-104

Teacher 1: "Advanced learners dictionary and this is my favorite one."

Teacher 2: "I use an advanced learners ' dictionary but the internet is another source for me to learn new words."

Teacher 3:"I use an English- English dictionary. However, I can sometimes consult to some online dictionaries which give English meaning with an example sentence."

Teacher 4: "I use advanced learners dictionaries."

Teacher 5: "Advanced dictionary is the only one I use for years and I particularly like it."

Teacher 6: "I have an advanced dictionary and I use it for years."

The fact that they are using corpus based dictionaries indicates that corpus has already penetrated into the language teaching business through course materials such as dictionaries and some course book materials which were prepared based on large and representative samples of naturally occurring language data.

In conclusion, before the training workshops were conducted, the subject teachers' awareness towards corpus and corpus tools were limited with the general concept of corpus as a branch of applied linguistics. The use of corpus in the language classrooms was non- existent. The results of this case study show quite clearly that their awareness level towards the use of corpora, which is a mainstream practice in English linguistics, increased significantly.

\section{Conclusion}

We believe that more exposure and immediate focus should be given to the integration of corpus based language teaching materials and corpus tools to be used in the language learning process. In this qualitative case study, the data were obtained through an open ended interview and direct observation by one of the researchers. The following questions were investigated.

The first research question was asked to know the background of the subject teachers in terms of previous corpus experience, if any. The second one intended to reveal the EFL teachers' perceptions towards the use of corpus tools in their instruction and to investigate the role of corpus based tools in EFL curriculum. Another question was asking whether EFL teachers received any training so far in teaching with corpus. The final one was to explore teachers' priorities in using corpus and what features of corpus tools they consider as important in their teaching.

The responses to the first research question revealed that the participant EFL teachers had little or no contact with the corpus and corpus tools in their previous teaching. Only one participant teacher reported limited exposure and familiarity with the concept of corpus in her previous education life but added that she "had no idea of how to use it in her classroom". The other participants expressed almost complete lack of awareness towards it. They also added that following the corpus training process they became more aware of the corpus tools and how to integrate them into their teaching. Thus, we claim and the contention at the beginning of this study was that corpus and corpus tools needed to be popularized among language teachers in order to establish them firmly in foreign language teaching. A corpus training program is, therefore, needed for teachers for successful integration into their teaching. By doing so, it is hoped that more language teachers will be familiarized with the potential benefits of corpus based methodologies and corpus tools that are likely to bring more freedom and flexibility into the classroom teaching in ways that are not anticipated before. Moreover, a systematic familiarization with the basic foundations, implications and applications of corpus linguistics can help language teachers to bridge the gap between theory and practice. The teachers' responses in the study revealed that such a program is definitely needed for language teachers. This is, also, consistent with the 
literature that has argued for the need to train corpus users for the successful use of corpora (Cobb, 1997; Flowerdew, 1996; Kennedy \& Miceli, 2001).

The responses to the second research question revealed that there are some challenges to overcome in order to integrate corpus methodology and corpus tools into the actual language teaching classrooms and to raise language teachers' perceptions towards it as a teaching and learning tool. One challenge is that there is little opportunity to exploit corpus resources in the school curriculum and the language teachers, in general, keep a distance towards the use of corpus tools and methodology in the classrooms. Almost all the participant teachers stated that the language proficiency level of the students is an important determinant for the successful use of corpus in the classroom. "I think only the best students can use this tool efficiently but the others don't (T6)" indicates a strong belief that "corpus is designed for higher level learners rather than beginner ones (T5)". We believe that this is a crucially important task and in addition to their efforts to help improving corpus based language pedagogy, corpus researchers also need to spend huge efforts to reach language teachers and find out what they actually want and need. It is also possible that learners' use of corpus may facilitate their own learning by actively taking up in the data mining process. John and King 's (1991) "Data driven learning (DDL)" approach best supports this contention. According to DDL approach, purpose is stated as "the use in the classroom of computer-generated concordances to get students to explore the regularities of patterning in the target language" (Johns \& King, 1991, p. iii). Johns $(1988$, p. 15) also added that "the concordancer is one of the most powerful tools that we can offer the language learner". This is also consistent with the account of T5, who said "Ss are prone to make mistakes while making sentences especially when the target language and source language aren't close to each other. They can use corpus and correct the general grammatical mistakes and also it offers the daily expression in the target language". It is obvious that the integration of DDL activities into the classroom teaching is likely to increase the grammatical and lexical competency of the students by providing them with the lexical and grammatical patterns as well as the contextual information in which the patterns are used. The case study also showed that using corpus provided a framework of authentic and naturally occurring data. It also prepared the ground for reformulating the existing knowledge of grammar forms as well as studying the variations in words and words combinations in different registers and lexical context.

The responses to the third research question revealed that "academic writing and the translation" are the most suitable courses for corpus integration. Majority of the participant teachers responded that "It would be helpful for $L 2$ learners in writing courses while also they were writing articles and essays in their courses (T4)". Others, however, also added that they "can make use of corpus in translation (T6)". According to the T5, lexical competency can best be achieved through corpus integration. This is also consistent with the existing literature that lexicology, phraseology and corpus linguistics are generally dealt with together.

The responses to the fourth research question revealed that corpus concordances are the ideal and useful tools to be used in the classrooms. T1 stated that "I think corpus concordance is a very useful tool for comparing the words going together..." and T2 also stated that "Concordances provide contextual usages and they are really useful". T4, on the other hand, focused on the appropriate word selection feature of concordances with the example of "start or begin". These, once more, indicate the important functions of concordances as teaching tools in the language classrooms. It is evident from the subjects' self-reports that another important aspect of concordance is its ability to limit the context of search, a feature which is not available in dictionaries. Based on the responses elicited from the participant teachers' account of the corpus and corpus tools, it is possible to conclude that corpus tools and concordances are likely to create an environment for teachers and students which enable them to make decisions related to the English language through natural, authentic and comparatively reliable data. 
Yet, the researchers of this article observed several challenging issues during the study. All these problematic issues made us feel that there is a long way to go before corpus can be understood and successfully integrated into the classroom. During and after the training sections, the subjects presented us with several problematic issues, which are related to the lack of:

- effort for the training of novice language teachers in basic corpus skills in general,

- knowledge to apply corpus based curriculum into their classes with a curriculum where corpus is not mentioned at all

- awareness towards descriptive nature of corpus based findings as opposed to prescriptive nature of language teaching,

- $\quad$ ready- made classroom materials and integrated tasks

\section{Limitations of the Study and Implications for Further Research}

There are some limitations to this study which need to be acknowledged. First of all this was a case study that was conducted with a limited number of subjects and, therefore, generalizations that can be made as a result of this small scale case study presented here must be regarded with caution. There is a need for conducting a similar study with more language teachers and in several universities in an attempt to explore the effect of such corpus based language training with language teachers for their actual classroom practices. More extensive training workshops need to be done and more ready-made course materials should be prepared to increase the corpus literacy of language teachers to successfully teach with corpora. Finally, the training workshops underlying the case study presented here were done in a Turkish University and therefore, the results are shaped and influenced by the characteristics of this specific environment. 


\title{
Geniş Özet
}

\begin{abstract}
Giriş
Son yıllarda teknolojik aletlerin eğitim öğretim de kullanılmasıyla birlikte dil araştırmalarında da kayda değer gelişmeler meydana geldi. Bilgisayarlı derlemin ortaya çıkması ve yaygın bir şekilde kullanılması buna örnek olarak verilebilir. İlk olarak 1987`lerde Sinclair ile başlayan bilgisayarlı derlem çalışmaları daha sonradan genişleyerek devam etmiş ve günümüze kadar ulaşmıştır. Günümüzde derlem ve derlem tabanlı araçların yabancı dil öğretmenleri için çok zengin ve etkili bir alan olduğunu ama bunların kullanımımınım derlem okuryazarlığını artırmaktan geçtiğini de söylemek gerekir.

Ortaya çıkmasından itibaren çok geçmeden derlem ve derlem araç gereçlerinin yabancı dil öğretiminde nasıl kullanılacakları sorusu zihinleri meşgul etti (Burnard \& McEnery 2000; Aston 2001). Dahasi bu konudaki farkındalığın az olması hem öğretmenler ve hem de öğrenciler bazında derlem kullanımı ile ilgili bir takım kuşkularıda meydana getirdi. Esasında derslerde kullanılan kitapların bir bölümünün derlem tabanlı hazırlanmış olması bile bu konudaki farkındalığı artırmak için yeterli olmamıştır (Mukherjee 2004; Boulton 2009; Frankenberg-Garcia 2010; Gilquin \& Granger 2010). Tribble`a (2000) göre bu durumun sebebi " yabancı dil öğretmenlerinin derlemi sınıflarında doğrudan kullanmıyor " olmaları olabilir. Seidlhofer” a (2002) göre ise bu durumun temel sebebi farkındalık seviyesinin çok düşük olmasındandır.
\end{abstract}

Bütün bu sorular derlemi sınıf içinde etkili olarak nasıl kullanabiliriz sorusunu akla getirmektedir. Mukherjee' ye (2004) göre yapılması gereken ilk şey yabancı dil öğretmenlerini bu konuda eğitmek ve onların derlem tabanlı öğretim materyallerini kullanabilmesine imkan sağlamaktır (Römer, 2005). Johns ve King (1991), Tribble ve Jones (1997), Aston (2001), Sinclair (2004), Bennet (2010), ve Reppen (2010) gibi araştırmacılar "Veri Yönetimli Öğrenme" yönteminin yabancı dil sınıflarında uygulamaya sokulmasını önerirken derlem kullanımımın öğretmen ve ögrenci açısından faydalarını vurgulamak istemişler ve farkındalık seviyesini artırmada faydali olacağını öngörmüşlerdir. Ayrıca derlem kullanımında yabancı dil öğretmenlerinin sahip olması gereken "derlem okuryazarlığının" yanında öğrencilerde de derlem kullanımı hakkında destek vermesi gerekliliği ortaya çıkmıştır.

\section{Yöntem}

\section{Araştırma Deseni}

Bu örnek olay incelemesi çalışması, bilgisayarlı derlem ve derlem araçlarını yabancı dil öğretim ve öğrenim süreçlerine entegre edebilme çabasıyla yapılmıştır. Altı yabancı dil öğretmeni çalışmanın denekleri olmuşlar ve onlara atölye çalışması şeklinde haftada 3 saat olmak üzere toplam sekiz haftalık bir eğitim verilmiştir. Çalışmanın birinci amacı Kolb un (1984) yetişkinler için "somut örnekler, gözlem ve düşünme yoluyla öğrenim" olarak özetlediği "deneysel öğrenim döngüsü" çerçevesinde denek öğretmenler için bir yetişkin öğrenme ortamı oluşturmaktı. Sonraki aşamada denek öğretmenlerden öğretmen rollerine geri dönüp derlem kullanımı ile ilgili edindikleri tecrübeleri sınıflarında kullanmaları istenmiştir. Atölye çalışması sırasında denek öğretmenler derlem tabanlı öğretim materyalleri hazırlamışlar ve bunları ilave ders materyali olarak kullanma imkanlarına sahip olmuşlardır. Son aşamada deneklerden "eğitim esnasında edindikleri dil öğrenim tecrübelerini ve bunların kendi dil öğretimlerine yansımaları" ilkesine dayalı olarak düşünmeleri istenmiştir (Muller-Hartmann \& Schocker-von Ditfurth, 2004). 


\section{Katılımcılar}

Çalışma 2013 yılında, Karadeniz Teknik Üniversitesi, Yabancı Diller Yüksekokulu, Temel İngilizce bölümü İngilizce hazırlık sınıflarında görev yapan toplam altı (6) İngilizce öğretmeni ile yapılmıştır. Denekler amaçlı örnekleme ve gönüllülük esasına göre seçilmiş ve haftalık ortalama 30 saat dilbilgisi, okuma, yazma ve dinleme-anlama dersi veren öğretmenlerden oluşmuşlardır. Deneklerin yaş ortalaması 27 olup en az 4 yıllık tecrübeye sahip öğretmenlerden seçilmişlerdir. Biri dışında diğer tüm denekler İngiliz Dil Eğitimi bölümünden mezun olmuşlardır.

\section{Kullanılan Veri Toplama Araçları}

Çalışma örnek olay incelemesine dayalı olduğu için öğretmenler ile 8 hafta süren bir atölye çalışması yapılmıştır. Bu süre bitiminde denekler ile açık uçlu mülakat yöntemi kullanılarak yüz yüze görüşülmüş ve değişen algılar nitel olarak tespit edilmeye çalışılmıştır.

\section{Veri Analizi}

Veriler yarı yapılandırımış mülakat yoluyla ve nitel olarak analiz edilmiştir. Analizde deneklerin değişen algıları tespit edilmeye çalışılmıştır. Mülakat sırasında toplam 4 soru sorulmuş ve sorular deneklerin derleme karşı değişen algılarını, derlem kullanırken yaşadıkları güçlükleri ve genel düşüncelerini almak için sorulmuştur.

\section{Sonuçlar}

Çalışmanın sonuçları göstermiştir ki deneklerin derlem tecrübesi çok sınırlı kalmış ve bu sınırlı bilgi onların sınıf içinde derlemi başarılı bir şekilde kullanabilmeleri için yeterli olmamıştır. Bir diğer bulgu deneklerin derlem kullanımını hem kendileri hem de öğrencileri için yararlı ve etkili bir aktive olduğunu düşünmeleridir. Diğer taraftan deneklerin çoğu derlemin akademik yazma ve çeviri derslerinde kelime seçiminde en çok kullanılabilineceğini düşünmeleridir. Son olarak denekler derlemlerdeki dizinlerin öğrencileri için kelime seçimi, karşılaştırılması, eş güdümlü kelimeleri bulmaları ve aradaki farkları görmeleri açılarından çok faydalı olacağını düşünmeleridir.

\section{Tartısma}

Derlem taban dil öğretim araç gereçlerinin dil öğretim ve öğrenim süreçlerine daha fazla dahil edilmesinin gerekli olduğuna inanıyoruz. Bu nitel örnek durum çalışmasında veriler yarı yapılandırılmış mülakat yoluyla toplandı. illk soru deneklerin derlem geçmişleri ile ilgiliydi. Deneklerin geçmişte derlem hakkında ya hiç ya da çok sınırlı derecede bilgi sahibi oldukları çalışma sonuncunda anlaşıldı. Bunun da derlem kullanımının yabancı dil öğretmenleri arasında yaygınlaştırılması için iyi bir gerekçe olduğunu düşünüyoruz. Derlem hakkında kuramsal bilgilerinin mutlak derlem uygulamaları ile pratiğe dökülmesinin gerekliliği ortadadır (Cobb, 1997; Flowerdew, 1996; Kennedy ve Miceli, 2001).

İkinci araştırma sorusu derlem tabanlı dil öğretim yöntemini dil sınıflarına entegre edebilmenin önünde bazı engeller olduğunu ortaya çıkardı. Bunlardan bir tanesi okul müfredatında derlem tabanlı dil çalışmaları yapmak için hemen hemen hiç bir uygun aktivite olmadığı idi. Ayrıca öğrencilerin dil seviyeleri zaman zaman derlem kullanımı için uygun olmadığı sonucu ortaya çıktı. Derlemin dil seviyesi yüksek sınıflarda etkili bir şekilde kullanılabilineceği sonucuna varıldı.

Diğer bir araştırma sorusu ise derlemin en çok çeviri ve akademik yazma derslerinde öğrenciler için faydalı olabileceği sonucunu ortaya çıkardı. Son olarak derlem tabanlı öğretim materyallerinin derslerde çok faydalı olabileceği ile ilgili bir fikir birliği ortaya çıktı. 
Ali Şükrü ÖZBAY, M. Naci KAYAOĞLU- Çukurova Üniversitesi Eğitim Fakültesi Dergisi, 44(1), 2015, 85-104

Bütün bu sonuçlara rağmen araştırmacılar olarak biz, çalışma esnasında çeşitli sorunlar tespit ettik. Bütün bu sorunsallar bize derlem tabanlı dil eğitimin yabancı dil sınıflarında yerini bulmasının zaman alacağını gösterdi. Bu sorunları kısaca aşağıdaki gibi özetleyebiliriz:

Temel derlem bilgisine sahip yeni yabancı dil öğretmenleri yetiştirmenin gerekliliği

- Derlemin kendine yer bulamadığı bir okul müfredatı içinde derlem tabanlı uygulamalar yapmanın zorlukları

- Derlem tabanlı betimsel bulguların dil öğretiminde kullanılan kuralcı yaklaşıma uygun olmaması

- Hazır ders materyallerinin ve entegre materyallerin derlem tabanlı olmaktan uzak olması

\section{Kaynakça}

Allan, Q. (1999). Enhancing the language awareness of Hong Kong teachers through corpus data: The Telenex experience. Journal of Technology and Teacher Education, 7(1), 57-74.

Anthony, L. (2004). AntConc (Version 3.0.1) [Software]. Retrieved July 10, 2008, from http://www.antlab.sci.waseda.ac.jp/antconc_index.html.

Aston, G. (ed.) (2001). Learning with corpora, Houston, TX: Athelstan.

Aston, G. (2000). Corpora and language teaching. In L. Burnard and T. McEnery (Eds), Rethinking language pedagogy from a corpus perspective: Papers from the Third International Conference on Teaching and Language Corpora (pp. 7-17). Frankfurt am Main: Peter Lang.

Best, J. \& Kahn, J. (1998). Research in Education ( $8^{\text {th }}$ edition). USA: A Viacom Company.

Bernardini, S. (2000). Systematising serendipity: Proposals for concordancing large corpora with language learners. In L. Burnard and T. McEnery (eds), Rethinking language pedagogy from a corpus perspective: Papers from the Third International Conference on Teaching and Language Corpora (pp. 225-234). Frankfurt am Main: Peter Lang.

Bennet, G. (2010). Using corpora in the language learning classroom: Corpus linguistics for teachers. Michigan: University of Michigan Press.

Biber, D., Conrad, S., \& Reppen, R. (1996). Corpus-based investigations of language use. Annual Review of Applied Linguistics, 16, 115-136.

Boulton, A. (2009). Data-driven learning: reasonable fears and rational reassurance. Indian Journal of Applied Linguistics 35 (1), 81-106.

Blaxter, L. Hughes, C., \& Tight, M. (1996). How to Research. Buckingham: Open University Press.

Braun, S. (2005). From pedagogically relevant corpora to authentic language learning contents. ReCALL, 17(1), 47-64.

Burnard, L., \& T. McEnery (eds) (2000), Rethinking language pedagogy from a corpus perspective: Papers from the Third International Conference on Teaching and Language Corpora, Frankfurt am Main: Peter Lang.

Cobb, T. (1997). Is there any measurable learning from hands-on concordancing? System, 25(3), 301315.

Cohen, L., \& Manion, L. (1995). Research Methods in Education. London: Routlage.

Farr, F. (2008). Evaluating the use of corpus-based instruction in a language teacher education context: Perspectives from the users. Language Awareness, 17(1), 25-43. 
Flowerdew, L. (2001), The exploitation of small learner corpora in EAP materials design. In M. Ghadessy, A. Henry, and R.L. Roseberry (eds), Small corpus studies and ELT: Theory and practice, pp. 363379.Amsterdam: John Benjamins.

Flowerdew, J. (1996). Concordancing in language learning. M. Pennington (Ed.), The power of CALL. pp. 97-113. Houston, TX: Athelstan.

Frankenberg-Garcia, A. (2010). "Encouraging EFL teachers to use corpora in the classroom". BAAL and Cambridge University Press Seminar Using corpus evidence in the classroom: Working with teachers and learners. University of Birmingham, 24-25 June 2010.

Gavioli, L. (2001), The learner as researcher: Introducing corpus concordancing in the classroom. In G. Aston (ed.), Learning with corpora, pp. 108-137. Houston, TX: Athelstan.

Gilquin, G., \& S. Granger (2010). How can DDL be used in language teaching? In A. O'Keeffe \& M. McCarthy (eds.), The Routledge handbook of corpus linguistics, pp. 359-370. London: Routledge.

Granger, S., \&. Tribble C. (1998), Learner corpus data in the foreign language classroom: Form focused instruction and data-driven learning, in S. Granger (ed.), Learner English on computer, pp. 199-209. London: Longman.

Granger, S. (ed.) (1998), Learner English on Computer. London: Longman.

Hunston, S. (1995). Grammar in teacher education: The role of a corpus. Language Awareness, 4(1), 1531.

Johns, T. (1991), Should you be persuaded?: Two examples of data-driven learning materials, English Language Research Journal, 4, 1-16.

Johns, T., \& King, P., (Eds.). (1991). Classroom concordancing. Birmingham: University of Birmingham

Johns, T. (1988). Whence and whither classroom concordancing? In T. Bongaerts, P. de Haan, Lobbe S., \& H. Wekker (Eds.), Computer applications in language learning (pp. 9-27). Dordrecht: Foris.

Kaltenbo“ ck, G., \& Mehlmauer-Larcher, B. (2005). Computer corpora and the language classroom: On the potential and limitations of computer corpora in language teaching. ReCALL, 17(1), 65-84.

Kayaoğlu, M. N. (1997). An investigation of the learning strategies of Turkish EFL and ESL adult learners and the relationship between their beliefs about different aspects of language learning and their strategy use. Unpublished doctoral dissertation, University of Bristol, Bristol.

Kennedy, C., \& Miceli, T. (2001). An evaluation of intermediate students' approaches to corpus investigation. Language Learning and Technology, 5(3), 77-90

Kolb, D.A. (1984). Experiential learning: Experience as the source of learning and development. Englewood Cliffs, NJ: Prentice-Hall.

Mukherjee, J. (2002). Korpuslinguistik und Englischunterricht. Eine Einführung. Frankfurt: Peter Lang.

Muller-Hartmann, A., \& Schocker-von Ditfurth, M. (2004). Introduction to English language teaching. Stuttgart: Ernst Klett Sprachen.

Mukherjee, J. (2004). Bridging the gap between applied corpus linguistics and the reality of English language teaching in Germany. In U. Connor \& T. Upton (Eds.), Applied corpus linguistics: A multidimensional perspective, (pp. 239-250). Amsterdam, NewYork: Rodopi.

O’Keefe, A., \& Farr, F. (2003). Using language corpora in initial teacher education: Pedagogic issues and practical applications. TESOL Quarterly, 37(3), 389-418. 
Ali Şükrü ÖZBAY, M. Naci KAYAOĞLU- Çukurova Üniversitesi Eğitim Fakültesi Dergisi, 44(1), 2015, 85-104

Oppenheim, A.N. (1992). Questionnaire Design, Interviewing and Attitude Measurement. London: Pinter Publishers

Reppen, R. (2010). Using corpora in the language classroom. New York: Cambridge University Press.

Römer, Ute (2005). Progressives, Patterns, Pedagogy. A Corpus-driven Approach to English Progressive Forms, Functions, Contexts and Didactics. Amsterdam: John Benjamins

Hasselgård, H., \& Johansson, S. (2001). Learner corpora and contrastive interlanguage analysis. In A Taste for Corpora: In honour of Sylviane Granger: Fanny Meunier \& Sylvie De Cock \& Gaëtanelle Gilquin \& Magali Paquot(eds), 32-61. Amsterdam: John Benjamins B.V.

Seidlhofer, B. (2002). Pedagogy and local learner corpora: Working with learning-driven data. In S. Granger, J. Hung \& S. Petch-Tyson (Eds.), Computer learner corpora, second language acquisition and foreign language teaching (pp. 213-234). Amsterdam, Philadelphia: John Benjamins.

Sinclair, J.M. (ed.) (1987), Looking up: An account of the COBUILD project in lexical computing, London: Collins.

Sinclair J. (ed.) (2004). How to use corpora in language teaching. Amsterdam and Philadelphia: John Benjamins.

Tsui, A.B.M., (2004). What teachers have always wanted to know and how corpora can help. In J.M. Sinclair (Ed.), How to use corpora in language teaching (pp. 39-61). Amsterdam, Philadelphia: John Benjamins.

Tribble, C. (2000). Practical uses for language corpora in ELT. In P. Brett \& G. Motteram (Eds.), A special interest in computers : Learning and teaching with information and communications technologies (pp. 31-41). Whistable, Kent: IATFEL.

Tribble, C., \& Jones, G. (1997). Concordances in the classroom: A resource guide for teachers. Houston, TX: Athelstan

Woods, D. (1996). Teacher Cognition in Language Teaching: Beliefs, decision-making and classroom practice. GB: Cambridge University Press. 